\title{
Minimum acceptable diet and stunting among children aged 6-23 months in Dalit and Non-Dalit and associated factors: A cross-sectional comparative study of Dhanusha district, Nepal
}

Anil Kumar Sah ( $\nabla$ kumaranil2065@gmail.com )

Nepal Health Research Council https://orcid.org/0000-0002-0480-6170

Rajan Paudel

Tribhuvan University Institute of Medicine

Madhu Dixit Devkota

Tribhuvan University Institute of Medicine

Ramesh Sigdel

Tribhuvan University Institute of Medicine

Ashok Pandey

Nepal Health Research Council

Research article

Keywords:

Posted Date: October 30th, 2019

DOI: https://doi.org/10.21203/rs.2.16627/v1

License: (c) (i) This work is licensed under a Creative Commons Attribution 4.0 International License. Read Full License 


\begin{abstract}
Background The complementary feeding practices are essential for development and survival of infant and young child, it reduces the risk of under-nutrition. The aim of the study was to assess the status and identify factors associated with minimum acceptable diet and stunting among children aged 6-23 months in Dalit and Non-Dalit.Methods A cross-sectional comparative study was conducted in Dhanusha district among mother who has 6-23 months children. Altogether 599 respondents were taken of which 299 were from Dalit and 300 from Non-Dalit and used multistage simple random sampling. Interview and anthropometry measurement were used for data collection technique and structure questionnaire as a tool. Descriptive and inferential analyses were done by using Statistical Package for the Social Science (SPSS).Results The prevalence of minimum acceptable diet (MAD) and stunting were $43.8 \%$ and $49.9 \%$ among Dalit while $44.3 \%$, and $39 \%$ among Non-Dalit. The MAD were significantly associated with the age of child (AOR=0.25, 95 Cl: $0.11-0.54)$, child illness in the past two weeks (AOR=4.31, 95\% Cl: 1.56-11.88) and child of mother who had no knowledge on child feeding (AOR=0.31, 95\% Cl: $0.16-0.61)$ among Dalit while age of child ( $A O R=0.37,95 \mathrm{Cl}: 0.21-0.64$ ), child illness in past two weeks ( $\mathrm{AOR}=4.80,95 \% \mathrm{Cl}$ : $2.23-10.32$, child mother who had no knowledge on child feeding (AOR=0.26, 95\% Cl: 0.16-0.42) and birth interval (AOR=1.92, 95\% Cl: 1.56-3.19) among Non-Dalit. Stunting was significantly associated with family types (AOR=1.93, 95\% Cl: 1.11-3.34) among Dalits while Ante Natal Care (ANC) visit (AOR=3.20, 95\% Cl: 1.15-8.90), media exposure (AOR=3.10, 95\% Cl: 1.118.64 and age of child (AOR=0.24, 95\% Cl: 0.10-0.57) in Non-Dalit.Conclusion This study shows that the age of child, child illness and knowledge on child feeding are the key associated factors of the MAD practices in both Dalits and Non-Dalits, while birth interval also among Non-Dalits. Similarly, family type is a key associated factors of stunting in Dalits while age of child, ANC visit and media exposure among Non-Dalits. Community based awareness raising appropriates child feeding and nutrition and related implementation program could be needed for improving the nutritional status of children.
\end{abstract}

\title{
Background
}

Being essential, nutrition of children contribute to survive, to develop and to grow among children[1]. Undernutrition prejudices cognitive and physical development and enhances the risk for children mortality and morbidity[2]. Stunting, a major outcome of children development provide long term and irreversible profound effect on individual as well as society[3]. Child feeding practices, an important for child growth and development more ever helps to make lower morbidity and mortality for under two years[4] while inappropriate feeding practices direct to the risk of malnutrition[5]. More than two-thirds of malnutrition occurs during the golden 1000 days of life which is due to inappropriate feeding practices[6].

Worldwide, stunting, among 165 millions of children leads towards a serious public health concern[7]. Undernutrition among children enhances dominance in developing countries[8]. In past few decades of Nepal, the pattern of stunting has declined[9,10]. However, high proportions of the child of this age still remain affected which adds a serious public health concern of Nepal[1]. From the ancient time in Nepal, "Dalit" were considered as a schedule caste, poorest and untouchable[11]. Dalit is divided into two groups; Hilly Dalit and Terai Dalit in Nepal[11]. Terai Dalit includes Chamar/Harijan, Musahar, Dushad/Pasman, Tatma, Khatwe, Dhobi, Baantar, Chidimar, Dom and Halkhor whereas Hill Dalit includes Kami, Damai/Dholi, Sarki, Badi, Gaine and Unidentified Dalit[11]. People other than Dalit caste considers as Non-Dalits. The proportion of stunting was $37.4 \%$ at National level but it was high at the central Terai region (41.6\%) among under-five aged children[12]. The proportion of minimum acceptable diet (MAD) was 18.9\% in Dalit while it was $32.73 \%$ in Non-Dalit population[2]. Children of Dalit have lower MAD compared to Brahmin/Chhetri, Newar and Janajati[2].

Children of the golden 1000 days of age are prone to high risk groups of undernutrition. Insufficient complementary feeding[8], family types[13] age of child[14,15,16] maternal education $[14,16,17]$ and knowledge on child feeding being the key factors have contributed to stunting. Furthermore, sociodemographic, health and knowledge are also associated with MAD such as Ante Natal Care (ANC) $[15,18,19]$ age of a child [15,20,21], knowledge on child feeding[22,23] and child illness [20,24].

However, sufficient nutrition, a pre-requisite for sustainable development goal[25], gets a fundamental right of every child[26]. Appropriate follow a MAD with dietary diversity reduce the threat of stunting[7]. Improving child feeding practices pave the way for the highest priority program with an aim to improve children nutrition and health[27]. This study might give an important situation of stunting and minimum acceptable diet which could be baseline information for nutritional intervention. Thus, this study aims to assess the prevalence of minimum acceptable diet and stunting among children aged 6-23 months in Dalits and Non-Dalits and associated factors.

\section{Methods}

\section{Study design and setting}

A cross sectional comparative study was conducted in Dhanusha district of Nepal, between October 2016 to March 2017.The total area of the districtcovers 1,180 square kilometers and Maithili is the commonly spoken language[28]. The south part of the district is attached with the Bihar border of India. The selected Village Development Committees (VDC) covers about 5-30 kilometers East, North and South from headquarter (Janakpur).

\section{Study population, Sample size calculation and sampling procedure}

Children aged 6-23 months and their mothers in Dalit and Non-Dalit were the study population who were living in Dhanusha district. The sample size was calculated by using two population proportion groups [29]. The prevalence of minimum dietary diversity of Dalit and Non-Dalit was taken as $20.1 \%$ and $31.32 \%$ respectively[2]. By taking power $85 \%$, level of significance $5 \%$ and non-response rate $5 \%$, the sample size was 599 , where 299 from Dalit and 300 from Non-Dalit. Multi-stage simple random sampling was applied in the study. Initially, three out of seven electoral constituencies were selected and three VDCs were chosen from each electoral constituency by randomly. Finally four wards out of nine wards of each VDC selected randomly by using lottery method. 
Bahedabela, Fulgama, Nagaraen, Dhabauli, Panchaharba, Sonigama, Sinujoda, Sapahi and Shantipur were picked VDCs. List of children aged 6-23 months were obtained from Vitamin A and Immunization registers. Furthermore, the proportional allocation was considered to estimate the number of children to participate in each selected ward. In the case of more than one child, the young child was purposively selected. Moher who had 18 years and above were involved in the study. Two repeated visits were made when mother-child pairs were not available at the time of data collection.

\section{Data collection techniques, tools and procedure}

Pre-testing was completed among $10 \%$ of the respondents in Bateshwar VDC. The data collection tool was adopted from Nepal Demographic Health Survey[9] and it was modified in the local context, the questionnaire was translated to the native language (Maithili) to maintain uniformity in the responses. Socioeconomic and demographic, health, child feeding and anthropometry and information of mother/family were included in the questionnaire. Community Medical Assistants (CMA) were recruited as enumerators for data collection. Training was given to enumerators which contains the questionnaire, ethical consideration, anthropometric measurements and data collection techniques. Face to face interviews was conducted with child mothers by using structured questionnaire and child height was measured by recommended standard measuring instruments.

\section{Data quality and safety}

A day training was given to enumerators. Pretested tool was used and each day cross-checked was made for completeness, clarity, consistency and accuracy by researcher. Researcher himself was involved in the monitoring and supervision of enumerators' through the study. Password protected laptop was used for data entry and analyzed by one door system.

\section{Data processing and analysis}

Data were edited, coded and entered into the EpiData 3.1 version. The data was exported in SPSS 16.0 version for analysis. For anthropometry analysis, World Health Organization (WHO) anthropometry nutrition survey tool was used. Nutrition-related data were analyzed by using the WHO Anthro plus software 3.2 .2 version. The Z-score of height-for-age (HAZ) was calculated, HAZ less than -2 standard deviations (SD) was defined as stunted from the reference population.

In the descriptive analysis, frequency and percentage were used to summarize the study variables. A binary logistic model was used to find out associated factors. P-value of $<0.2$ in bivariate analysis were entered to the multivariable analysis to control the possible effect of confounders[30]. Hosmer and Lemeshow Chi-square to get whether the model was fit. Enter method was used to see the independent association between dependent and independent variables. The adjusted odds ratio (AOR) with $95 \%$ confidence interval was used to notify the strength of association, and at $95 \% \mathrm{Cl}$ was used to declare the statistical significance in the multivariate analysis.

\section{Ethical consideration}

The research proposal was approved by the Institutional Review Committee of Institute of Medicine, Tribhuvan University, Maharajgunj; each respondent was informed on the objective, method and benefit of the study and written informed consent was taken before taking the interview. Using identifiable number, the confidentiality was maintained.

\section{Results}

\section{Socio-demographic characteristics}

A total of 599 respondents were taken, 299 from Dalit and 300 from Non-Dalit (Table 1). The mean age ( \pm Standard Deviation, SD) children were 14.5( \pm 4.7) months in Dalit whereas 14.4 ( \pm 4.6) months in Non-Dalit. The high proportion of children were female (56.9\%) in Dalit while male (55.7\%) in Non-Dalit. Most of Dalit child mothers were housewife (58.9\%) followed by labour (24.1\%) and were illiterate (83.0\%) whereas Non-Dalit child mothers were housewife (66.0\%) followed by agriculture (25.3\%) and were illiterate (44.3\%).

\section{Knowledge, child health and feeding related characteristics}

Nearly two-fifth of children had child illness in past two weeks in Dalit (19.4\%) while in Non-Dalit (18.7\%) (Table 2). Most of child mother had knowledge on child feeding in Dalit (51.8\%) and Non-Dalit (60.0\%).About two-fifth of children received minimum acceptable diet practices in Dalit (43.8\%)whereas in NonDalit (44.3\%) (Table2). Most of the female children had minimum acceptable diet practices in Dalit (47.6\%) and Non-Dalit (38.8\%) (Table 3). About half of children aged 12-23 months received MAD in Dalit (50.0\%) and Non-Dalit (49.3\%) (Table 3).

\section{Child stunting related characteristics}

The proportion of moderate and severe stunting among children were $31.8 \%$ and $18.1 \%$ in Dalit while $27.0 \%$ and $12.0 \%$ in Non-Dalit respectively (Table 2). The prevalence of stunting (below minus 2SD) among children aged 6-23 months was $49.9 \%$ in Dalit while $39.0 \%$ in Non-Dalit. Besides, the prevalence of

Page 3/11 
stunting was high among female children in Dalit (51.8\%) and also in Non-Dalit (39.8\%) (Table 3). About half of children were stunted among children aged 12-23 months (51.4\%) and 9-11 months (51.0\%) in Dalit. But two- fifth of children aged 12-23 months were stunted in Non-Dalit (42.9\%).

\section{Factors associated with minimum acceptable diet}

The findings from multivariable logistic regression analysis indicated that the minimum acceptable diet practices were not found significantly associated with the sex of a child, father education, birth interval, family types, main source of family income and house hold owning agriculture land among Dalits (Table 4) while and family types, main source of family income, household owing agriculture land, ANC visit, place of delivery, Post Natal Care (PNC) visit, media exposure, number of child, and mother occupation in Non-Dalits (Table 5). The MAD practices were found less likely among children aged 6-11 months (AOR $=0.25,95 \%$ of $\mathrm{Cl}: 0.11-0.54)$ in Dalit and (AOR $=0.37,95 \%$ of $\mathrm{Cl}: 0.21-0.64)$ in Non-Dalit. The MAD practices were also found less likely among child mother who had knowledge of child feeding ( $A O R=0.31$, Cl: $0.16-0.61)$ in Dalit whereas ( $A O R=0.26,95 \%$ of $\mathrm{Cl}$ : $0.16-0.42)$ in Non-Dalit. The MAD practices were found higher among children who did not have illness than children who had illness among Dalit (AOR $=4.31,95 \%$ of $\mathrm{Cl}$ : $1.56-11.88)$ while also higher NonDalit (AOR $=3.02,95 \%$ of $\mathrm{Cl}$ : $1.35-6.73)$. The practices were also higher in the family with birth interval up to 2 years than more than 2 years in Non-Dalits $(\mathrm{AOR}=1.92,95 \%$ of $\mathrm{Cl}: 1.56-3.19)$.

\section{Factors associated with stunting}

The result of multivariable logistic regression analysis revealed that stunting were not significantly associated with knowledge on child feeding, ANC visit, media exposure and Timely Initiation of complementary feeding in Dalits (Table 6), while father education, birth interval, family types, household owning agriculture land, place of delivery, and mothers' occupation in Non-Dalits (Table 7). The stunting was found higher in children of single family (AOR = 1.93, 95\% of $\mathrm{Cl}$ : 1.11-3.34) compared to joint family in Dalits. Furthermore, it was found that stunting was also higher in child mother who did not have visit ANC (AOR = $3.20,95 \%$ of Cl: 1.15-8.90) than child mother who had visited ANC in Non-Dalit. Similarly, it was also found more likely among child mother who had not exposed to media as compare to child mother who had exposed to media in Non-Dalits (AOR $=3.10,95 \%$ of $\mathrm{Cl}$ : $1.11-8.64$ ). In addition, the stunting was protected among children aged $6-11$ months $(\mathrm{AOR}=0.24,95 \%$ of $\mathrm{Cl}$ : $0.10-0.57)$ than children aged $12-23$ months in Non-Dalit.

\section{Discussion}

The minimum acceptable diet gets a composite indicator of minimum dietary diversity and minimum meal frequency[31]. The findings revealed that the prevalence of MAD were about two-fifth among children aged 6-23 months in Dalit (43.8\%) and Non-Dalit (44.3\%). The similar, magnitude of MAD practices mentioned in NDHS 2016 [10]. However, this practice was high in Sri Lanka (63.3\%)[32]. The resemblance of Dalit and Non-Dalit of MAD might be due to the occupations of the mothers and the same locality. The complementary feeding practices are generally irregular and unsupervised[33]. The current prevalence of MAD manifested that it still needs to promote the practices of MAD.

The findings showed that half of children aged 6-23 months were stunting in Dalit (49.9\%) while more than one-third in Non-Dalit (39.0\%). In comparison with the findings, Ethiopia (58.1\%)[34] and India(52.3\%)[35] had higher prevalence of stunting but lower in Sri Lanka (17.3\%)[32] and Nepal (35.6\%) [10]. The difference of stunting in Dalit and Non-Dalit might be due to the education of mother and father and the knowledge of mothers on child feeding. So, the existing magnitude of stunting recommended that the government should focus on the nutrition intervention programme.

The findings from multivariable logistic regression analysis revealed that the minimum acceptable diet practices did not find significant association with sex of child, father education, birth interval, family types, main source of family income and household owning agriculture land among Dalit while family type, main source of family income, household owing agriculture land, ANC visit, place of delivery, Post Natal Care (PNC) visit, media exposure, number of child, and mother occupation in Non-Dalit. Furthermore, this study revealed that minimum acceptable diet practice was protected among children aged 6-11 months as compared to children aged 12-23 months in Dalit and Non-Dalit. This findings got supported by the findings of somewhere else([15,18,19,21]. This study showed that one-fifth in Dalit (20.0\%) and more than one-fourth in Non-Dalit (29.7\%) of children got only MAD practices among children aged 6-11 month. In Nepal, mother breast milk seems to be sufficient for the first year of life to feed their children whenever children show their interest and generally, mothers used to feed rice and legume to their children[33]. However, complementary feeding practices make essential in this age because breast feeding gets inadequate after six months of child[36]. So, inadequate child feedings becomes risky for growth faltering among children of Nepal[36].

The findings revealed that the minimum acceptable diet was less likely among child mothers who had no knowledge of child feeding as compared to child mothers who had knowledge on child feeding in Dalit and Non-Dalit. The result got supported from a study conducted in Nepal[23]. About one-fifth of mother practiced MAD among their children, having no knowledge of child feeding might be due to the association of knowledge on child feeding with MAD. The evidence from systematic review showed that lack of knowledge was a key barriers of optimal complementary feeding practice[37]. In Nepal, a study showed the inadequate minimum acceptable diet practices would be due to poor knowledge on child feeding practices [19]. A study shows that lack of awareness regarding frequency of feeding as well as diversified nutrient taking behavior might be the risk of undernutrition among children. So, maternal nutrition education might help to promote complementary feeding practice among children[15].

The result showed that MAD practices was more likely among children with birth interval upto 2 years than children with birth interval above 2 years in NonDalit. The findings was contrast with a study conducted in South Ethiopia[38] and Nigeria[39] because of the different study's settings. A study showed more the increasing of the birth-interval more the decreasing of child undernutrition and mortality[40]. This might be due to mothers who fed her elder child and at the same time they fed younger child. 
The findings showed that MAD practice was more probably among children who had no illness in past two weeks as compared to children who had illness in past two weeks in Dalit and Non-Dalit. This result got supported by the study conducted in Sri Lanka [20]. In Nepal, about three-fifth of child mother (59\%) fed the same amount of food during episodes of diarrhea and about one-fourth of mother (24\%)fed lesser than usual feeding[41]. But one-fourth of mother (29\%) increased food during child illness as it mentions in NDHS[10]. Child feeding got reduced due to child illness that may affect health of child[20].

The study reveals that the stunting was protected among children aged 6-11 as compared to 12-23 months whereas only one-fifth of children aged 6-11 months had stunting in Non-Dalit. This result got supported by the findings of a study conducted in Ethiopia[34] and Indonesia[42]. This findings also got supported by the findings of somewhere else[43]. Stunting was less likely among children below six months as they depend on breastfeeding[44]. Some mothers feed breast milk till a year and they feed solid food whenever children show interest[33]. Poor child feeding practices become recognized contributor to undernutrition among this age $[45,46]$.

This study manifested that the stunting were more likely among children living with the nuclear family than joint family in Dalit. The findings got supported from the study conducted in Nepal [47] and Kenya[48]. The findings gets contrast with a study conducted in Pakistan [49]. This findings showed about onefourth of Dalit child mothers (24.1\%) working as a daily wage/labor and they might be unable to care their children properly. Mothers involving in the work outside setting were taking their children with them did not feed in time, which might effect on child complementary feeding practices[33].Children living in a joint family get appropriate care by someone (for example-grand-parents) during busy of her/his mother.

The findings stated that the stunting was more likely among child mother who did not visit ANC than child mother who visited ANC in Non-Dalit and half of children were stunting who did not visit ANC. This findings got supported by the study conducted in Indonesia[42]. Adequate ANC visit might help to enhance knowledge regarding appropriate child feeding practices and got opportunity of appropriate counseling regarding child care. This result indicated that the stunting was more likely among the mother who did not expose to media than mother who exposed to media in Non-Dalit. This findings got supported from the study of Bangladesh [50]. The media provides information regarding overall knowledge on child health and nutrition, which might help to reduce the stunting [50].

The comparative studies showed the prevalence of minimum acceptable diet and stunting and associated factors among children aged 6-23 months. Naturally, it is not free from some limitations. The complementary feeding practices were not observed but it depended on the response of mothers which might be exaggerated by social desirability bias and recall bias.

\section{Conclusions}

The study revealed that the proportion of minimum acceptable diet practice resembles in Dalit and Non-Dalit children. This practice gets similar to the national figure, but insignificant to the countries that have better health indicators. But it did not get satisfactory level in this region because of the key associated factors; age of child, knowledge on child feeding and child illness within past 2 weeks in both groups whereas birth interval only in Non-Dalit. The prevalence of stunting was higher in Dalit than Non-Dalit. But it also got higher than National figure[10]. Stunting got higher in both groups which indicate the serious public health concern among children. In addition, type of family becomes an important associated factor of stunting among Dalit whereas age of child, ANC visit, and media exposure among Non-Dalit.

So, the findings of the study confirm that there have been quiet rooms to improve infant and child feeding and reduce stunting among children in Nepal. Improving maternal nutrition education, access and utilization of health services and promoting the exposed to media would be helped in promoting infant young child feeding practices and reducing stunting.

\section{Abbreviations}

ANC: Ante natal care; AOR: Adjusted odds ratio; BCC: Behaviour change communication; Cl: Confidence interval; CMA: Community medicine assistant; COR: Crude odds ratio; HAZ: Height for age; MAD: Minimum acceptable diet; NDHS: Nepal demographic health survey; PNC: Post-natal care; SD: Standard deviation; SPSS: Statistical package for social sciences; VDC: Village development committee; WHO: World health organization.

\section{Declarations}

\section{Ethical approval and consent to participate}

Ethical approval was obtained from the Institutional Review Committee of Institute of Medicine, Nepal [Ref No.95 (6-11-E) $2 / 073 / 074]$. Permission was taken from District Public health Office, Dhanusha. This study did not involve any invasive procedure and a type observational study. So, the study posed no risk to study participants. Accordingly, all eligible child of mother were shared about the aim and method of the study and written Informed consent was taken. Furthermore, confidentiality was maintained and they had right to withdraw at any time from the study.

\section{Consent to Publish}

Not applicable

\section{Availability of data and materials}




\section{Competing interests}

The abstract was presented on 4th summit of Nepal Health Research Council.

The authors declare that they don't have competing interests.

\section{Funding}

Dr. Hark Gurung New ERA fellowship provided some grant after the data collection for completing study. The funding institution was not involved in study design, data collection, analysis and interpretation. So, the views of article are only of the authors.

\section{Authors' contribution}

AKS conceived the study, developed the tool, coordinated data collection, conducted the inferential analysis and drafted the manuscript. RP, MDD, and RS supported during the proposal development (Literature review, study design, methodology, ethical approval). AP supported in editing of the manuscript. All authors have read and approved the final manuscript.

\section{Acknowledgements}

We would like to thank child of mothers for their willingness to participate in the study. We would also like thank Female Community Health Volunteers, Health Post in charges, District Public Health Offices Dhanusha, enumerators and who support directly and indirectly and Department of Community medicine and Public Health, Institute of Medicine. We would like to acknowledge Nepal Health Research Council because author got data analysis and management training. The author knew details of multivariable logistic regression for example; condition of variables enter logistic regression $(P<0.2)$ after the training. Before training, author shared in different presentation without applying this criteria. We would like to acknowledge Mr. Sujit Kumar Sah who edits the language.

\section{Authors' information}

${ }^{1}$ Department of Community Medicine and Public Health, Maharajgunj Medical Campus, Institute of Medicine, Tribhuvan University, Nepal

${ }^{2}$ Nepal Health Research Council

\section{References}

1. Government of Nepal, Ministry of Health and Population, Deparment of Health Service, Child Health Division. 2014. Strategy for infant and young child feeding: Nepal 2014.

https://www.humanitarianresponse.info/sites/www.humanitarianresponse.info/files/documents/files/iycf_strategy_final_draft_18th_sept_014_english.pd Accessed 26 August 2019.

2. Crum J, Subedi G, Mason J, Mebrahtu S, Dahal P. 2013. Infant and Young Child Feeding Practices as Associated with Child Nutritional Status in Nepal; Analysis of the Nepal Demographic Health Survey 2011. Kathmandu, Nepal; Nepal Mininstry of Health and Population and UNICEF.

3. World Health Organization. WHA global nutrition targets 2025: stunting policy brief. Geneva: WHO. 2014:1-6.

4. WHO. Infant and young child feeding. 2018. https://www.who.int/en/news-room/fact-sheets/detail/infant-and-young-child-feeding. Accessed 21 April 2019.

5. Saleem AF, Mahmud S, Baig-Ansari N, Zaidi AK. Impact of maternal education about complementary feeding on their infants' nutritional outcomes in lowand middle-income households: a community-based randomized interventional study in Karachi, Pakistan. Journal of health, population, and nutrition. 2014 Dec;32(4):623.

6. Chaturvedi A, Nakkeeran N, Doshi M, Patel R, Bhagwat S. Capacity of frontline ICDS functionaries to support caregivers on infant and young child feeding (IYCF) practices in Gujarat, India. Asia Pacific journal of clinical nutrition. 2014 Nov 1;23.

7. Bhutta ZA, Das JK, Rizvi A, Gaffey MF, Walker N, Horton S, Webb P, Lartey A, Black RE, Group TL, Maternal and Child Nutrition Study Group. Evidencebased interventions for improvement of maternal and child nutrition: What can be done and at what cost?. The lancet. 2013 Aug 3; $382(9890): 452-77$.

8. Black RE, Allen LH, Bhutta ZA, Caulfield LE, de Onis M, Ezzati M, Mathers C, Rivera J, Maternal and Child Undernutriton Study Groups. Maternal and child undernutrition: global and regional exposures and health consequences. The lancet. 2008 Jan; 371(9608):243-60.

9. Ministry of Health and Population (MOHP) [Nepal], New ERA and ICF International Inc. 2012. Nepal Demogrphic and Health Survey 2011. Kathmandu, Nepal: Ministry of Health and population, New ERA, and ICF International, Calverton, Maryland.

10. Ministry of Health Nepal, New ERA and ICF. 2017. Nepal Demographic and Health Survey 2016. Kathmandu Nepal: Ministry of Health, Nepal. 
11. Pandey JP, Dhakal MR, Karki S, Poudel P, Pradhan MS. 2013. Maternal and child health in Nepal: the effects of caste, ethnicity, and regional identity further analysis of the 2011 Nepal Demographic and Health Survey. Ministry of Health and Population.

12. Central Bureau of Statistics 2015. Nepal Multiple Indicator Cluster Survey 2014, final report. Kathmandu, Nepal: Central Bureau of Statistics and UNICEF Nepal.

13. Bhanderi D, Choudhary SK. An epidemiological study of health and nutritional status of under five children in semi-urban community of Gujarat. Indian journal of public health. 2006;50(4):213-9.

14. Das S, Gulshan J. Different forms of malnutrition among under five children in Bangladesh: a cross sectional study on prevalence and determinants. BMC Nutrition. 2017 Dec;3(1):1.

15. Menon P. The crisis of poor complementary feeding in South Asia: where next? Maternal \& child nutrition. 2012 Jan;8:1-4.

16. Zongrone A, Winskell K, Menon P. Infant and young child feeding practices and child undernutrition in Bangladesh: insights from nationally representative data. Public health nutrition. 2012 Sep;15(9):1697-704.

17. Kavosi E, Rostami ZH, Nasihatkon A, Moghadami M, Heidari M. Prevalence and determinants of under-nutrition among children under six: A crosssectional survey in Fars Province, Iran. International journal of health policy and management. 2014 Jul;3(2):71.

18. Patel A, Pusdekar Y, Badhoniya N, Borkar J, Agho KE, Dibley MJ. Determinants of inappropriate complementary feeding practices in young children in India: secondary analysis of National Family Health Survey 2005-2006. Maternal \& child nutrition. 2012 Jan; 8:28-44.

19. Joshi N, Agho KE, Dibley MJ, Senarath U, Tiwari K. Determinants of inappropriate complementary feeding practices in young children in Nepal: secondary data analysis of Demographic and Health Survey 2006. Maternal \& child nutrition. 2012 Jan;8:45-59.

20. Senarath U, Godakandage SS, Jayawickrama H, Siriwardena I, Dibley MJ. Determinants of inappropriate complementary feeding practices in young children in Sri Lanka: secondary data analysis of Demographic and Health Survey 2006-2007. Maternal \& child nutrition. 2012 Jan;8:60-77.

21. Kassa T, Meshesha B, Haji Y, Ebrahim J. Appropriate complementary feeding practices and associated factors among mothers of children age 6-23 months in Southern Ethiopia, 2015. BMC pediatrics. 2016 Dec;16(1): 131.

22. Sethi R, Padhy S, Raju DV. Knowledge, attitude and practices regarding complementary feeding among mothers of children 6 to 24 months of age in Konaseema region. International Journal of Contemporary Pediatrics. 2017;4(2):394-8.

23. Chapagain R. Factors affecting complementary feeding practices of Nepali mothers for 6 months to 24 months children. Journal of Nepal Health Research Council. 2013 May 27; 11(24):205-7.

24. Senarath U, Dibley MJ. Complementary feeding practices in South Asia: analyses of recent national survey data by the South Asia Infant Feeding Research Network. Maternal \& child nutrition. 2012 Jan;8:5-10.

25. Government of Nepal. Ministry of Health and Population.2015. Department of Health Service. Annual Report 2014/2015. Kathmandu. https://dohs.gov.np/wp-content/uploads/2016/06/Annual_Report_FY_2071_72.pdf. Accessed 23 April 2019.

26. Government of Nepal. 2015. The Constitution of Nepal. https://www.mohp.gov.np/downloads/Constitution of Nepal 2072_full_english.pdf. Accessed 23 April 2019.

27. Sanghvi T, Haque R, Roy S, Afsana K, Seidel R, Islam S, Jimerson A, Baker J. Achieving behaviour change at scale: Alive and Thrive's infant and young child feeding programme in Bangladesh. Maternal \& child nutrition. 2016 May;12:141-54.

28. UNRCHCO. District Profile: Dhanusha. http://un.info.np/Net/NeoDocs/View/4227. Accessed 23 April 2019.

29. Charan J, Biswas T. How to calculate sample size for different study designs in medical research? Indian journal of psychological medicine. 2013 Apr;35(2):121.

30. Mekonnen TC, Workie SB, Yimer TM, Mersha WF. Meal frequency and dietary diversity feeding practices among children 6-23 months of age in Wolaita Sodo town, Southern Ethiopia. Journal of Health Population and Nutrition. 2017 Dec;36(1):18.

31. World Health Organization. Indicators for assessing infant and young child feeding practices: part 1: measurement.

32. Department of Census and Statistics (DCS) and Ministry of Health N and Indigenous Medicine 2017. Sri Lanka Demographic and Health Survey 2016 Sri Lanka.www.statistics.gov.lk. Accessed 23 April 2019.

33. Adhikari RK. 2010. Food utilization practices, beliefs and taboos in Nepal: An overview. United States Agency International Development.

34. Derso T, Tariku A, Biks GA, Wassie MM. Stunting, wasting and associated factors among children aged 6-24 months in Dabat health and demographic surveillance system site: A community based cross-sectional study in Ethiopia. BMC Pediatrics. 2017 Dec;17(1):96.

35. Deshmukh PR, Sinha N, Dongre AR. Social determinants of stunting in rural area of Wardha, Central India. Medical journal armed forces India. 2013 Jul1;69(3):213-7.

36. Victora CG, De Onis M, Hallal PC, Blossner M, Troph D, Shrimpton R. Worldwide timing of growth faltering: revisiting implications for interventions. Pediatrics. 2010 Mar1;125(3):e473-80.

37. Manikam L, Prasad A, Dharmaratnam A, Moen C, Robinson A, Light A, Ahmed S, Lingam R, Lakhanpaul M. Systematic review of infant and young child complementary feeding practices in South Asian families: the India perspective. Public health nutrition. 21(4):637-54.

38. Epheson B, Birhanu Z, Tamiru D, Feyissa GT. Complementary feeding practices and associated factors in Damot Weydie District, Welayta zone, South Ethiopia. BMC public health. 2018 Dec;18(1):419.

39. Issaka AL, Agho KE, Page AN, Burns PL, Stevens GJ, Dibley MJ. Determinants of suboptimal complementary feeding practices among children aged 6-23 months in four anglophone West African countries. Maternal \& child nutrition. 2015 Oct;11(1):14-30. 
40. Rutstein SO. Effects of preceding birth intervals on neonatal, infant and under-five years mortality and nutritional status in developing countries: evidence from the demographic and health surveys. International Journal of Gynecololy \& Obstetrics. 2005 Apr;89:S7-24.

41. Ministry of Health and Population (MOHP) [Nepal], New ERA and Macro International Inc. 2007. Nepal demographic and health survey 2006. Kathmandu, Nepal: Ministry of health and population. New ERA, and Macro International Inc.

42. Titaley CR, Ariawan I, Hapsari D, Muasyaroh A, Dibley MJ. Determinants of the stunting of children under two years old in Indonesia: A multilevel analysis of the 2013 Indonesia Basic Health Survey. Nutrients. 2019 May;11(5):1106.

43. Griffiths PL, Bogin BA, Madise NJ, Goudet SM. Nutritional interventions for preventing stunting in children(0 to 5 years) living in urban slums in low and middle-incomecountries (LMIC). The Cochrane Database of Systematic Reviews. 2015 May; 2015(5).

44. Thiombiano-Coulibaly N, Rocquelin G, Eymard-Duvernay S, Traoré SA. Effects of early extra fluid and food intake on breast milk consumption and infant nutritional status at 5 months of age in an urban and a rural area of Burkina Faso. European journal of clinical nutrition. 2004 Jan;58(1):80-9.

45. Lutter CK, Daelmans BM, de Onis M, Kothari MT, Ruel M, Arimond M, Dewey KG, Blossner M, Borghi E. Undernutrition, poor feeding practices, and low Coverage of key nutrition interventions. Pediatrics. 2011 Dec 1;128(6):1418-27.

46. Dewey KG, Brown KH. Update on technical issues concerning complementary feeding of young children in developing countries and implications for intervention programs. Food and nutrition bulletin. 2003;24(1):5-28.

47. Sapkota VP, Gurung C. Prevalence and predictors of underweight, stunting and wasting in under-five children. Journal of Nepal Health Research Council. 2010 Mar 30;7(2):120-6.

48. Neervoort F, Von Rosenstiel I, Bongers K, Demetriades M, Shacola M, Wolffers I. Effect of a school feeding programme on nutritional status and anaemia in an urban slum: a preliminary evaluation in Kenya. Journal of tropical pediatrics. 2012 Dec 12;59(3):165-74.

49. Mian RM, Ali M, Ferroni P, Underwood P. The nutritional status of school-aged children in an urban squatter settlement in Pakistan. Pakistan J of Nutrition. 2002;1(3):121-3.

50. Sarma H, Khan JR, Asaduzzaman M, Uddin F, Tarannum S, Hasan MM, Rahman As, Ahmed T. Factors influencing the prevalence of stunting among children aged below five years in Bangladesh. Food and nutrition bulletin. 2017 Sep; 38(3):291-301.

\section{Tables}

Table1: Socio-demographic and economic characteristics of children and their mothers

\begin{tabular}{lrrrrr}
\hline \multirow{2}{*}{ Characteristics } & \multicolumn{2}{c}{ Dalits (n=299) } & \multicolumn{3}{c}{ Non-Dalits (n=300) } \\
\cline { 2 - 6 } & Number (n) & Percentage (\%) & Number (n) & Percentage (\%) \\
\hline Age ofchild (in months) & & & & \\
\hline $6-8$ & 30 & 10.0 & 37 & 12.3 \\
\hline 9-11 & 51 & 17.1 & 46 & 15.3 \\
\hline 12-23 & 218 & 72.9 & 217 & 72.3 \\
\hline Mean age \pm SD & $14.51 \pm 4.678$ & & $14.42 \pm 4.560$ \\
\hline Sex of child & & & & \\
$\quad$ Male & 129 & 43.1 & 167 & 55.7 \\
\hline Female & 170 & 56.9 & 133 & 44.3 \\
\hline Mother's occupation & & & & \\
\hline Housewife & 176 & 58.9 & 198 & 66.0 \\
\hline Agriculture & 49 & 16.4 & 76 & 25.3 \\
\hline Labour & 72 & 24.1 & 8 & 2.7 \\
\hline Others & 2 & 0.7 & 18 & 6.0 \\
Mother education & & & & \\
\hline$\quad$ Illiterate & 248 & 83.0 & 133 & 44.3 \\
\hline Primary & 16 & 5.4 & 33 & 11.0 \\
\hline$\quad$ Some secondary & 25 & 8.4 & 82 & 27.3 \\
SLC and above & 10 & 3.3 & 52 & 17.3 \\
\hline
\end{tabular}

Table 2: Nutrition, health and knowledge related characteristics of children and their mother 


\begin{tabular}{|c|c|c|c|c|c|c|}
\hline \multirow[t]{2}{*}{ Characteristics } & \multicolumn{3}{|c|}{ Dalits $(n=299)$} & \multicolumn{3}{|c|}{ Non-Dalits $(n=300)$} \\
\hline & Number (n) & \multicolumn{2}{|c|}{ Percentage (\%) } & Number (n) & \multicolumn{2}{|c|}{ Percentage (\%) } \\
\hline \multicolumn{7}{|c|}{ Minimum acceptable diet } \\
\hline Yes & & 131 & 43.8 & & 133 & 44.3 \\
\hline No & & 168 & 56.2 & & 167 & 55.7 \\
\hline \multicolumn{7}{|l|}{ Stunting } \\
\hline Normal & & 68 & 22.7 & & 90 & 30.0 \\
\hline Mild & & 82 & 27.4 & & 93 & 31.0 \\
\hline Moderate & & 95 & 31.8 & & 81 & 27 \\
\hline Severe & & 54 & 18.1 & & 36 & 12.0 \\
\hline \multicolumn{7}{|c|}{ Child illness in past two weeks (Diarrhea/ARI/Fever) } \\
\hline Yes & & 58 & 19.4 & & 56 & 18.7 \\
\hline No & & 241 & 80.6 & & 244 & 81.3 \\
\hline \multicolumn{7}{|c|}{ Knowledge on child feeding } \\
\hline Yes & & 155 & 51.8 & & 180 & 60.0 \\
\hline No & & 144 & 48.2 & & 120 & 40.0 \\
\hline
\end{tabular}

Table 3: Age and sex-wise status of minimum acceptable diet and stunting among children

\begin{tabular}{|c|c|c|c|c|}
\hline \multirow[t]{2}{*}{ Characteristics } & \multicolumn{2}{|c|}{ Dalits $(n=299)$} & \multicolumn{2}{|c|}{ Non-Dalits $(n=300)$} \\
\hline & $\begin{array}{c}\text { MAD } \\
\text { Yes-n(\%) }\end{array}$ & $\begin{array}{l}\text { Stunting } \\
\text { Yes-n(\%) }\end{array}$ & $\begin{array}{c}\text { MAD } \\
\text { Yes-n(\%) }\end{array}$ & $\begin{array}{l}\text { Stunting } \\
\text { Yes-n(\%) }\end{array}$ \\
\hline \multicolumn{5}{|l|}{ Sex } \\
\hline Male & $50(38.8)$ & $61(47.3)$ & $72(43.1)$ & 64(38.3) \\
\hline Female & $81(47.6)$ & $88(51.8)$ & $61(45.9)$ & $53(39.8)$ \\
\hline \multicolumn{5}{|c|}{ Age of child (months) } \\
\hline $6-8$ & $6(20.0)$ & 11(36.7) & 11(29.7) & $6(16.2)$ \\
\hline $9-11$ & $16(31.4)$ & $26(51.0)$ & $15(32.6)$ & 18(39.1) \\
\hline $12-23$ & $109(50.0)$ & $112(51.4)$ & $107(49.3)$ & 93(42.9) \\
\hline
\end{tabular}

MAD: Minimum acceptable diet, $\mathrm{n}=$ number, $\%=$ Percentage

Table 4 A multivariable logistic regression showing the factors associated with minimum acceptable diet among children aged 6-23 months in Dalits

\begin{tabular}{|c|c|c|c|c|}
\hline \multirow[t]{2}{*}{ Characteristics } & \multicolumn{2}{|c|}{ Minimum acceptable diet } & \multirow{2}{*}{$\begin{array}{c}\text { COR } \\
\text { (95\% of CI) }\end{array}$} & \multirow{2}{*}{$\begin{array}{c}\text { AOR } \\
\text { (95\% of CI) }\end{array}$} \\
\hline & Met n(\%) & Not-Met n(\%) & & \\
\hline \multicolumn{5}{|l|}{ Age of child } \\
\hline 12-23 Months & $109(50.0)$ & $109(50.0)$ & 1 & 1 \\
\hline 6-11 Months & $22(27.2)$ & $59(72.8)$ & $0.37(0.21-0.65)$ & $0.25(0.11-0.54)^{*}$ \\
\hline \multicolumn{5}{|l|}{ Sex of child } \\
\hline Female & $81(47.6)$ & $89(52.4)$ & 1 & 1 \\
\hline Male & $50(38.8)$ & $79(61.2)$ & $0.70(0.44-1.11)$ & $0.68(0.35-1.29)$ \\
\hline \multicolumn{5}{|l|}{ Father education } \\
\hline Secondary and above & $44(52.4)$ & $40(47.6)$ & 1 & 1 \\
\hline Upto primary & $87(40.5)$ & $128(59.5)$ & $0.62(0.37-1.03)$ & $0.46(0.21-1.02)$ \\
\hline \multicolumn{5}{|l|}{ Child illness } \\
\hline Yes & $8(13.8)$ & $50(86.2)$ & 1 & 1 \\
\hline No & $45(54.9)$ & $37(45.1)$ & $6.52(2.96-14.32)$ & $4.31(1.56-11.88)^{*}$ \\
\hline \multicolumn{5}{|l|}{ Birth interval } \\
\hline Above 2 years & $28(39.4)$ & $43(60.6)$ & 1 & 1 \\
\hline Upto 2 years & $70(50.0)$ & $70(50.0)$ & $1.54(0.86-2.74)$ & $1.68(0.83-3.38)$ \\
\hline \multicolumn{5}{|l|}{ Family types } \\
\hline Joint & $92(41.1)$ & 132(58.9) & 1 & 1 \\
\hline Nuclear & $39(52.0)$ & $36(48.0)$ & $1.55(0.92-2.63)$ & $0.46(0.21-1.02)$ \\
\hline \multicolumn{5}{|l|}{ Main source of income } \\
\hline Non-agriculture & $109(42.2)$ & $149(57.8)$ & 1 & 1 \\
\hline Agriculture & $22(53.7)$ & $19(46.3)$ & $1.58(0.82-3.07)$ & $1.07(0.40-2.90)$ \\
\hline \multicolumn{5}{|c|}{ Knowledge on child feeding } \\
\hline Yes & $92(61.3)$ & $58(38.7)$ & 1 & 1 \\
\hline No & $39(26.2)$ & $110(73.8)$ & $0.22(0.14-0.37)$ & $0.31(0.16-0.61)^{*}$ \\
\hline \multicolumn{5}{|c|}{ Household ownership on agriculture land } \\
\hline Yes & $58(35.8)$ & $104(64.2)$ & 1 & 1 \\
\hline No & $73(53.3)$ & $64(46.7)$ & $0.49(0.31-0.78)$ & $0.79(0.37-1.67)$ \\
\hline
\end{tabular}

*: significant (CI :> 1or <1), COR: Crude odds ratio, AOR: Adjusted odds ratio, n: number, CI: Confident interval. 
Table 5: A multivariable logistic regression showing the factors associated with minimum acceptable diet among children aged 6-23 months in Non-Dalits

\begin{tabular}{|c|c|c|c|c|}
\hline \multirow{2}{*}{ Characteristics } & \multicolumn{2}{|c|}{ Minimum acceptable diet } & \multirow{2}{*}{$\begin{array}{c}\text { COR } \\
\text { (95\% of } \mathrm{CI})\end{array}$} & \multirow{2}{*}{$\begin{array}{c}\text { AOR } \\
\text { (95\% of } \mathrm{CI} \text { ) }\end{array}$} \\
\hline & Met n(\%) & Not-Met n(\%) & & \\
\hline \multicolumn{5}{|l|}{ Age of child } \\
\hline 12-23 Months & $107(49.3)$ & $110(50.7)$ & 1 & 1 \\
\hline 6-11 Months & $26(31.3)$ & $57(68.7)$ & $0.47(0.28-0.80)$ & $0.37(0.21-0.64)^{*}$ \\
\hline \multicolumn{5}{|l|}{ Child illness } \\
\hline Yes & $10(17.9)$ & $46(82.1)$ & 1 & 1 \\
\hline No & $123(50.4)$ & $121(49.6)$ & $4.68(2.26-9.69)$ & $4.80(2.23-10.32)^{*}$ \\
\hline \multicolumn{5}{|l|}{ Birth interval } \\
\hline Above 2 years & $33(43.4)$ & $42(56.6)$ & 1 & 1 \\
\hline Upto 2 years & $49(55.7)$ & $39(44.3)$ & $1.64(0.88-3.04)$ & $1.92(1.56-3.19)^{*}$ \\
\hline \multicolumn{5}{|l|}{ Family types } \\
\hline Joint & $107(42.5)$ & $145(57.5)$ & 1 & 1 \\
\hline Nuclear & $26(54.2)$ & $22(45.8)$ & $1.60(0.86-2.98)$ & $1.72(0.98-3.01)$ \\
\hline \multicolumn{5}{|c|}{ Main source of family income } \\
\hline Non-agriculture & $82(41.4)$ & $116(58.6)$ & 1 & 1 \\
\hline Agriculture & $51(50.0)$ & $51(50.0)$ & $1.42(0.88-2.29)$ & $1.19(0.65-2.19)$ \\
\hline \multicolumn{5}{|c|}{ Knowledge on child feeding } \\
\hline Yes & $103(61.3)$ & $65(38.7)$ & 1 & 1 \\
\hline No & $30(22.7)$ & $102(77.3)$ & $0.19-0.11-0.31)$ & $0.26(0.16-0.42)^{*}$ \\
\hline \multicolumn{5}{|c|}{ Household ownership on agriculture land } \\
\hline Yes & $121(46.7)$ & 138(53.3) & 1 & 1 \\
\hline No & $12(29.3)$ & $29(70.7)$ & $0.47(0.23-0.97)$ & $0.72(0.39-1.33)$ \\
\hline \multicolumn{5}{|l|}{ ANC visit } \\
\hline Yes & $110(41.7)$ & $154(58.3)$ & 1 & 1 \\
\hline No & $23(63.9)$ & $13(36.1)$ & $2.45(1.20-5.10)$ & $1.71(0.91-3.20)$ \\
\hline \multicolumn{5}{|l|}{ Place-wise delivery } \\
\hline Health facilities & $57(35.0)$ & $106(65.0)$ & 1 & 1 \\
\hline Home & $76(55.5)$ & $61(44.5)$ & $2.32(1.45-3.69)$ & $0.84(0.15-4.66)$ \\
\hline \multicolumn{5}{|l|}{ PNC visit } \\
\hline Yes & $58(35.4)$ & $106(64.6)$ & 1 & 1 \\
\hline No & $75(55.1)$ & $61(44.9)$ & $2.25(1.41-3.58)$ & $1.45(0.26-7.99)$ \\
\hline \multicolumn{5}{|l|}{ Media exposure } \\
\hline Yes & $81(46.0)$ & $95(54.0)$ & 1 & 1 \\
\hline No & $50(40.7)$ & $73(59.3)$ & $0.61(0.31-1.18)$ & $0.62(0.34-1.12)$ \\
\hline \multicolumn{5}{|l|}{ Number of child } \\
\hline Two or more & $83(50.6)$ & $81(49.4)$ & 1 & \\
\hline Single & $50(36.8)$ & $86(63.2)$ & $0.57(0.36-0.90)$ & - \\
\hline \multicolumn{5}{|l|}{ Mother occupation } \\
\hline Non-housewife & $55(53.9)$ & $47(46.1)$ & 1 & 1 \\
\hline Housewife & $78(39.4)$ & $120(60.6)$ & $0.56(0.34-0.90)$ & $0.97(0.59-1.59)$ \\
\hline
\end{tabular}

*: significant (CI :> 1 or <1), COR: Crude odds ratio, AOR: Adjusted odds ratio, n: number, CI: Confident interval, ANC: Ante natal care.

Table 6: A multivariable logistic regression showing the factors associated with stunting among children aged 6-23 months in Dalits

\begin{tabular}{|c|c|c|c|c|}
\hline \multirow[t]{2}{*}{ Characteristics } & \multicolumn{2}{|c|}{ Stunting } & \multirow{2}{*}{$\begin{array}{c}\text { COR } \\
\text { (95\% of } \mathrm{CI})\end{array}$} & \multirow{2}{*}{$\begin{array}{c}\text { AOR } \\
(95 \% \text { of } \mathrm{CI})\end{array}$} \\
\hline & Stunted & Normal & & \\
\hline \multicolumn{5}{|l|}{ Family types } \\
\hline Joint & $102(45.5)$ & $122(54.5)$ & 1 & 1 \\
\hline Nuclear & $47(62.7)$ & $28(37.3)$ & $2.01(1.17-3.43)$ & $1.93(1.11-3.34)^{*}$ \\
\hline \multicolumn{5}{|c|}{ Knowledge on child feeding } \\
\hline Yes & $66(44.0)$ & $84(56.0)$ & 1 & 1 \\
\hline No & $83(55.7)$ & $66(44.3)$ & $1.60(1.01-2.53)$ & $1.59(0.99-2.54)$ \\
\hline \multicolumn{5}{|l|}{ ANC visit } \\
\hline Yes & $112(47.7)$ & $123(52.3)$ & 1 & 1 \\
\hline No & $37(57.8)$ & $27(42.2)$ & $1.51(0.86-2.63)$ & $1.17(0.65-2.12)$ \\
\hline \multicolumn{5}{|l|}{ Media exposure } \\
\hline Yes & $79(44.9)$ & $97(55.1)$ & 1 & 1 \\
\hline No & $70(56.9)$ & $53(43.1)$ & $1.62(1.02-2.58)$ & $1.56(0.94-2.58)$ \\
\hline \multicolumn{5}{|l|}{ TICF } \\
\hline Yes & $64(45.4)$ & $77(54.6)$ & 1 & 1 \\
\hline No & $85(53.8)$ & $73(46.2)$ & $1.41(0.89-2.21)$ & $1.57(0.97-2.54)$ \\
\hline
\end{tabular}

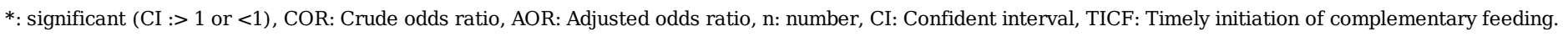


Table 7: A multivariable logistic regression showing the factors associated with stunting among children aged 6-23 months in Non-Dalits

\begin{tabular}{|c|c|c|c|c|}
\hline \multirow[t]{2}{*}{ Characteristics } & \multicolumn{2}{|c|}{ Stunting } & \multirow{2}{*}{$\begin{array}{c}\text { COR } \\
\text { (95\% of CI) }\end{array}$} & \multirow{2}{*}{$\begin{array}{c}\text { AOR } \\
\text { (95\% of } \mathrm{CI}) \\
\end{array}$} \\
\hline & Stuinted & Normal & & \\
\hline \multicolumn{5}{|l|}{ Age of child } \\
\hline 12-23 Months & 93(42.9) & 124(57.1) & 1 & 1 \\
\hline 6-11 Months & $24(28.9)$ & $59(71.1)$ & $0.54(0.31-0.94)$ & $0.24(0.10-0.57) *$ \\
\hline \multicolumn{5}{|l|}{ Father education } \\
\hline Secondary and above & $59(33.9)$ & $115(66.1)$ & 1 & 1 \\
\hline Upto primary & $58(46.0)$ & $68(54.0)$ & $1.66(1.04-2.66)$ & $1.18(0.56-2.46)$ \\
\hline \multicolumn{5}{|l|}{ Birth interval } \\
\hline Above 2 years & $34(44.7)$ & $42(55.3)$ & 1 & 1 \\
\hline Upto 2 years & $30(34.1)$ & $58(65.9)$ & $0.64(0.34-1.20)$ & $0.58(0.29-1.20)$ \\
\hline \multicolumn{5}{|l|}{ Family types } \\
\hline Joint & $91(36.1)$ & 161(63.9) & 1 & 1 \\
\hline Nuclear & $26(54.2)$ & $22(45.8)$ & $2.09(1.12-3.90)$ & $2.27(0.97-5.31)$ \\
\hline \multicolumn{5}{|c|}{ Household ownership on agriculture land } \\
\hline Yes & $96(37.1)$ & $163(62.9)$ & 1 & 1 \\
\hline No & $21(51.2)$ & $20(48.8)$ & $1.78(0.92-3.46)$ & $2.31(0.83-6.43)$ \\
\hline \multicolumn{5}{|l|}{ ANC visit } \\
\hline Yes & $99(37.5)$ & $165(62.5)$ & 1 & 1 \\
\hline No & 18(50.0) & 18(50.0) & $1.67(0.83-3.35)$ & $3.20(1.15-8.90) *$ \\
\hline \multicolumn{5}{|l|}{ Place of delivery } \\
\hline Health facilities & $58(35.6)$ & $105(64.4)$ & 1 & 1 \\
\hline Home & $59(43.1)$ & $78(56.9)$ & $1.37(0.86-2.18)$ & $0.98(0.47-2.04)$ \\
\hline \multicolumn{5}{|l|}{ Media exposure } \\
\hline Yes & $95(37.1)$ & 161(62.9) & 1 & 1 \\
\hline No & $22(50.0)$ & $22(50.0)$ & $1.70(0.89-3.22)$ & $3.10(1.11-8.64) *$ \\
\hline \multicolumn{5}{|l|}{ Mother occupation } \\
\hline Non-housewife & $45(44.1)$ & $57(55.9)$ & 1 & 1 \\
\hline Housewife & $72(36.4)$ & $126(63.6)$ & $0.72(0.45-1.18)$ & $0.64(0.31-1.33)$ \\
\hline
\end{tabular}

*: significant (CI :> 1 or <1), COR: Crude odds ratio, AOR: Adjusted odds ratio, n: number, CI: Confident interval. 